\title{
Ideové základy a niektoré obsahové črty rakúskej ústavy z roku 1934
}

\section{Ideological Foundations and Some Features of the Austrian Constitution of 1934}

Ján Drgo*

\begin{abstract}
Abstrakt
Clánok sa zameriava na analýzu spoločenských, politických, ale predov̌retkým ideových východísk rakúskej ústavy z roku 1934 založených na kritike parlamentnej demokracie a liberalizmu. Spomedzi jednotlivých ideových východísk ústavy kladie osobitný dôraz na autoritativny princíp prejavujúci sa v organizácii a pomere medżi zákonodarnou a výkonnou mocou v ústave. Práve tento pomer je totiž základným indikačným kritériom, na základe k.torého možno zistit', či koncepcia rakúskej ústavy predstavovala akési východisko medzi parlamentnou demokraciou na strane jednej a totalitnými systémami na strane drubej alebo naopak. ulahčovala nástup určitej formy autokracie či diktatúry.
\end{abstract}

\section{Klíčová slova}

Ústava; preambula; autoritativny; stavovský; Spolkový snem; poradné orgány; vláda.

\begin{abstract}
The article focuses on the analysis of the social, political but especially ideological origins of the 1934 austrian constitution based on criticism of parliamentary democracy and liberalism. Among the various ideological origins of the constitution, the article places special emphasis on the authoritarian principle manifesting itself in organization and the relationship between the legislative and executive powers of the constitution. It is precisely this relationship which is an indicator for that, if the austrian constitution was a kind of way between parliamentary democracy on the one hand and totalitarian systems on the other, or helped the emergence of a form of autocracy or dictatorship.
\end{abstract}

\section{Keywords}

Constitution; Preamble; Authoritarian; Corporative; Federal Diet; Advisory Bodies; Government.

\section{Úvod}

Rakúska ústava z roku 1934 patrila medzi tie ústavné texty medzivojnovej Európy, ktoré mali predstavovat' akési východisko z polarity medzi niekedy oprávnene kritizovanou demokraciou na strane jednej a totalitnými systémami sovietskeho či nacionálo-socialistického typu na strane druhej. Svojimi skôr konzervatívnymi ideovými východiskami sa tak približovala portugalskej ústave z roku 1933 a v podstatnej miere tiež ústave Slovenskej republiky z roku 1939. Napriek tomu, že tak portugalská a v menšej miere

* JUDr. Ján Drgo, PhD., Fakultná nemocnica s poliklinikou, Žilina, Slovenská republika/ Faculty Hospital with Polyclinic, Žilina, Slovak Republic / E-mail: jan.drgo@gmail.com 
aj slovenská ústava predstavovali značne originálne ústavné texty, ako sa mi azda podarilo preukázat' v niektorých mojich starších štúdiách, ${ }^{1}$ nedá sa hovorit’ o tom, že by vytvárali akúsi formu tretej cesty. Obe ústavy totiž v mene autoritatívneho princípu výrazne posilnili význam výkonnej moci (v prípade Portugalska osobitne úradu premiéra) v neprospech moci zákonodarnej, bez toho, aby vytvárali dostatočný systém bŕzd a protiváh. Hoci sa tvorcovia ústav dištancovali od totalitarizmu, práve takáto nerovnováha vytvárala živnú pôdu pre nástup určitej formy autokracie či diktatúry. Práve analýza rakúskej ústavy, ideovo blízkej tak portugalskej ako aj slovenskej ústave, dotvára obraz autoritatívnych ústav tým, že umožňuje načrtnuté závery potvrdit’ alebo naopak vyvrátit'. Ciel’om tohto článku je preto analyzovat' nielen spoločensko- politické okolnosti prijatia rakúskej ústavy, ale na príklade preambuly ústavy predovšetkým jej ideové východiská vrátane autoritatívneho princípu. Podrobnejšie sa článok venuje práve implementácii autoritatívneho princípu do ústavy, ked’že jeho dôsledky bolo osobitne badat' na pomere medzi zákonodarnou a výkonnou mocou. Práve tento pomer je rozhodujúcim indikátorom umožňujúcim zistit', či koncepcia rakúskej ústavy vytvárala dostatočný priestor pre spoločenskú pluralitu (napríklad prostredníctvom stavovského systému) alebo naopak predstavovala skôr východisko pre prechod k autokratickým formám vlády tak, ako to bolo v prípade Portugalska či Slovenskej republiky.

\section{Spoločenské a ideové východiská ústavy}

Kríza demokracie v Rakúsku začiatkom 30. rokov 20. storočia bola sprevádzaná postupným prehlbovaním politickej nestability. V roku 1931 sa o puč pokúsil štajerský Heimwehr. ${ }^{2}$ Prejavoval sa postupný nárast sympatií k národnému socializmu, pričom narastalo aj odmietanie parlamentarizmu a straníckeho systému. K celkovej nestabilite prispievalo i to, že vláda kancelára Engelberta Dollfußa (1892-1934) sa mohla od roku

1 Napr. DRGO, Ján. Úloha parlamentu v ústavách niektorých autoritatívnych štátov v medzivojnovej Európe. In: Ako právo reaguje na novoty. Bratislava: VEDA, 2015, s. 234 a nasl.; alebo DRGO, Ján. Výkonná moc $\mathrm{v}$ ústavách niektorých autoritatívnych štátov v medzivojnovej Európe. In: VOJÁČEK, Ladislav a Jaromír TAUCHEN (eds.). III. česko-slovenské právnébistorické setkáni doktorandů a postdoktorandů. Brno: Masarykova univerzita v Brně, 2015, s. 44 a nasl.; K teoretickým a praktickým aspektom fungovania autoritatívnych a totalitných režimov z pohladu politológie pozri napr. KUBÁT, Michal a Stanislav BALÍK. Teorie a praxe nedemokratických režimü. 2. vyd. Praha: Dokořán, 2012.

2 V Rakúsku sa po prvej svetovej vojne vytvorilo viacero polovojenských organizácí́. Lavici bol blízky Republikánsky ochranný zväz (Republikanische Schutzbund), zatial' čo pravicovému konzervatívnemu táboru boli blízke rozličné domobranecké zväzy označované spoločne ako Heimwehr. Heimwehr bol podporovaný aj spolkovým kancelárom Ignazom Seipelom, ktorý kritizoval tradičnú demokraciu a volal po vytvorení „pravej demokracie“. Samotný Heimwehr svoj odpor k tradičnej demokracii manifestoval 18. mája 1930 v takzvanej prísahe z Korneuburgu (Korneuburger Eid), v ktorej sa prihlásil k vlastenectvu, úsiliu o uchopenie moci a prestavbu štátu i hospodárskeho systému. Deklaroval tiež zavrhnutie „západného demokratického parlamentarizmu a stranickeho śtátu“ na ktorého miesto chcel postavit' stavovský a autoritatívny štát. In: SCHEUCH, Hanno. Austria 1918-55: From the First to the Second Republic. In: The Historical Journal, Cambridge Univesity Press, 1989, roč. 32, č. 1, s. 182 [cit. 23. 2. 2018]. Dostupné z: https://austria-forum.org/af/Wissenssammlungen/Schicksalsorte/Korneuburg_N\%C3\%96 
1932 opierat' v Národnej rade (Nationalrat) iba o majoritu jedného hlasu a v Spolkovej rade (Bundesrat) nemala dokonca ani takúto tesnú väčšinu.

Ked’ 4. marca 1933 odstúpili všetci traja prezidenti Národnej rady, spolková vláda tento krok prezentovala tak, že Národná rada sa „rozpustila sama“ (Selbstausschaltung des Parlaments), a tak otvorila cestu k autoritatívnemu štátu. Takémuto účelovému výkladu pomohla aj skutočnost’, že rokovací poriadok Národnej rady výslovne neobsahoval žiadnu úpravu pre prípad, že by odstúpili všetci traja jej prezidenti. Z takto vzniknutej krízy sa navrhovalo viacero východísk, pričom sa napokon rozhodlo, že Národná rada bude zvolaná tým prezidentom, ktorý odstúpil ako posledný. Ked' však tretí prezident Sepp Straffner ako posledný odstúpivší prezident oznámil zhromaždenie Národnej rady na 15. marca 1933, jej zasadnutiu zabránila spolková vláda so súhlasom spolkového prezidenta. ${ }^{3}$ Spolkovej vláde sa tak otvorila cesta $\mathrm{k}$ nastoleniu autoritatívneho režimu. Spolková vláda si však zároveň dala záležat’ na zachovaní zdania zákonnosti. Ako najschodnejšia varianta sa v tomto smere javilo využite takzvaného vojnového hospodárskeho zmocňovacieho zákona (RGBl. 307/1917, v texte d’alej len ako KWEG) ${ }^{4}$, z roku 1917, ktorý bol recipovaný aj do právneho poriadku povojnového Rakúska. Od roku 1933 sa však na jeho základe začali vydávat' aj také nariadenia, ktoré menili ústavu, pričom tieto nariadenia často nemali žiadny súvis s hospodárskym účelom, ktorý zákon pôvodne sledoval. ${ }^{5}$ Prvé nariadenie spolkovej vlády na základe KWEG, ktoré vyšlo niekol'ko dní po takzvanom samorozpustení parlamentu zavádzalo cenzúre podobné opatrenia. Ked’ sa Spolková rada, stelesňujúca záujmy jednotlivých spolkových krajín, odhodlala zrušit' vládou vydané nariadenia, zvolat' parlament a vypísat' nové vol’by, spolková vláda vyhlásila, že Spolková rada nie je v čase, ked’ neexistuje Národná rada zákonodarným orgánom a jej rozhodnutia tak z pohl'adu ústavného práva nemajú žiadny význam. ${ }^{6}$

Podobne ako vlády $\mathrm{v}$ iných európskych štátoch medzivojnového obdobia, ktoré sa postupne odkláňali od liberálnej demokracie, aj rakúska spolková vláda sa usilovala o minimalizáciu možných opozičných vystúpení voči vládnej politike. Komplikácie, ktoré mohli nastat' by mali jednak právnu povahu, najmä kvôli spornosti ústavnosti nariadení

3 BRAUNEDER, Wilhelm a Friedrich LACHMAYER. Österreichische Verfassungsgeschichte. Wien: Manzsche Verlag, 1989, s. 232. Straffnera poverila zvolaním Národnej rady vlastná vel'konemecká strana. Vláda pritom dala už predtým najavo, že pokial' sa ktokol'vek pokúsi o zvolanie Národnej rady, použije bližšie nešpecifikované prostriedky, čo sa aj stalo a Straffnerov pokus bol násilne rozohnaný políciou.

4 Kriegswirtschaftliches Ermächtigunsgesetz.

5 BRAUNEDER, Wilhelm a Friedrich LACHMAYER. Österreichische Verfassungsgeschichte. Wien: Manzsche Verlag, 1989, s. 232. Zrušenie KWEG navrhovala sporadicky vel'konemecká strana a sociálny demokrati. K požiadavke sociálnych demokratov na zrušenie KWEG na jeseň 1932 pozri napríklad: KRIECHBAUMER, Robert. Die großen Erzählungen der Politik. Politische Kultur und Parteien in Österreich vor der Jahrbundertwende bis 1945. Wien - Köln - Weimar: Böhlau Verlag, 2001, s. 229-230.

6 BRAUNEDER, Wilhelm a Friedrich LACHMAYER. Österreichische Verfassungsgeschichte. Wien: Manzsche Verlag, 1989, s. 233. 
vlády vydaných na základe KWEG, ale taktiež aj politickú povahu, ak by vládnu politiku začali napádat' opozičné strany.

Ked’že viedenská krajinská vláda napadla na ústavnom súde ku koncu apríla 1933 už desat' nariadení vydaných na základe KWEG, spolková vláda zabezpečila odstúpenie viacerých sudcov ústavného súdu, čo malo za následok, že ústavný súd sa dokonca mája 1933 v dôsledku ubúdania svojich členov „,rozpustil sám“ podobne ako Národná rada. Nasledoval útok na politické strany. Zákaz činnosti a rozpustenie sa najprv dotkli odporcov režimu. V roku 1933 hlavne komunistov a rakúskych národných socialistov. Vo februári 1934 zákaz postihol taktiež sociálnu demokraciu. Zo spočiatku neorganizovaného hnutia, ktoré bolo iniciované Engelbertom Dollfußom v roku 1933, a ktoré malo združovat' všetky sily stojace proti marxizmu a národnému socializmu sa vyvinul takzvaný Vlastenecký front (Vaterländische Front). ${ }^{7} \mathrm{~V}$ máji 1934 nadobudol spolu s ústavou účinnost’ spolkový zákon týkajúci sa Vlasteneckého frontu (BGBl. 4/1934-II). ${ }^{8}$ Vlastenecký front mal byt' nositel'om rakúskej štátnej myšlienky a mal tiež politicky zastrešovat’ všetkých štátnych príslušníkov v duchu novej ústavy a vlastenectva. V roku 1936 bol Vlastenecký front prehlásený za jediného predstavitel’a politickej vôle v štáte.

Základné myšlienky nového politického režimu načrtol spolkový kancelár Engelbert Dollfuß 11. septembra 1933 v prejave, ktorý predniesol na dostihovom okruhu Trabrennplatz vo Viedni. Myšlienky, ktoré tu Dollfuß prezentoval možno zaradit' do ideového rámca, ktorému bol v danej dobe azda najbližšie portugalský premiér António de Oliveira Salazar. Portugalec svoje ideové postoje prezentoval predovšetkým vo svojej reči z roku 1930 známej ako Základné princípy politickej revolúcie (Princípios fundamentais da revolução política). Salazar v tejto reči podl’a vlastných slov hovoril málo o slobode, demokracii a suverenite l’udu, ale zato ovel'a viac o poriadku, autorite, disciplíne, sociálnej súhre, národe a štáte. ${ }^{10}$ Prejav rakúskeho spolkového kancelára sa niesol v podobnom duchu. Dollfuß vo svojom prejave otvorene zaútočil na modernistické ideológie akými boli, respektíve stále sú liberalizmus či marxizmus, deklaroval tiež odmietnutie straníckeho systému. Podobne ako v prípade Salazara sa i v jeho prejave odzrkadloval

7 Vlastenecký front bol založený v máji 1933. Spočiatku zastával funkciu vodcu Vlasteneckého frontu spolkový kancelár Engelbert Dollfuß. Na jar 1934 sa jeho súčast’ou stal aj takzvaný Obranný front (Wehrfront), ktorého vedenie mal na starosti Ernst Rüdiger Starhemberg. Od októbra 1933 sa Starhemberg stal Dollfußovým zástupcom a po zavraždení spolkového kancelára v júli 1934 vodcom Vlasteneckého frontu. K tomu pozri: TÁLOS, Emmerich. Das austrofaschistische Herrschaftssystem. Österreich 1933-1938. 2. Auflage. LIT Verlag: Wien-Berlin, 2013, s. 147-150.

8 Bundesgesetz betrefend die Vaterländische Front.

9 BRAUNEDER, Wilhelm a Friedrich LACHMAYER. Österreichische Verfassungsgeschichte. Wien: Manzsche Verlag, 1989, s. 233.

10 Porovnaj: SALAZAR, António de Oliveira. The fundamental principles of the revolution. In: Contemporary Portugues History Online [online]. [cit. 8. 10. 2014]. Dostupné z: http://www.cphrc.org/index.php/ documents/militarydictatorship/143-1930-06-30-the-fundamental-principles-of-the-revolution; Pozri aj: MAYER, Anton. Portugal und sein Weg zum autoritären Staat. Leipzig: Wilhelm Goldmann, 1939, s. 57. 
nacionalizmus a viera v nadprirodzený poriadok vecí. „Keby som nebol preniknutý blbokou vierou, že cesta, ktorou kerácame je nám predpisaná z̧hora ako povinnost', keby som nebol preniknutý myšlienkou, že novo vąbudený pocit lásky k otčine je opät’ taký silný, že dokážžme odolat’ každému protivnikovi, nebol by som pocitil duševnú silu takto kevám prehovorit' a ist'po tejto ceste napred. "Dollfuß vo svojom prejave stanovil základnú programovú líniu rakúskeho štátu, ktorý sa mal stat' stavovským autoritatívnym štátom. „....chceme sociálny, krest’anský, nemecký štát Rakúsko na stavovskom základe pod silným, autoritativnym vedením. Autorita neznamená svojvôlu. Autorita znamená organizovanú moc, znamená vedenie zodpovednými, nesebeckými a obetavými l’ud’mi. "11

\section{Prijatie ústavy a jej základné ideové smernice}

Zásady, ktoré vo svojej reči proklamoval spolkový kancelár boli v právnej rovine realizované prijatím novej ústavy (Verfassung des Budesstaates Österreichs). Ústava bola vydaná dva krát, avšak obe znenia ústavy boli identické. Prvý krát bola ústava vydaná 24. apríla 1934 prostredníctvom nariadenia spolkovej vlády o ústave spolkového štátu Rakúsko (BGBl. 239/1934-I) ${ }^{12}$, ktoré bolo vydané na základe zmocnenia obsiahnutého v KWEG. Využite KWEG na vydanie ústavy však narážalo na to, že KWEG mal hospodársky účel a vydanie novej ústavy by tento účel istotne prekročilo. Problematické bolo i to, že ústava nebola predložená na l’udové hlasovanie tak, ako to vyžadoval čl. 44 ods. 2 vtedy platnej rakúskej ústavy z roku 1920 v znení z roku 1929 (d’alej len BVG). Aby sa odstránili tieto nedostatky, a aby sa vytvorila akási kontinuita s BVG, vláda prikročila k vydaniu nariadenia, ktorým zvolala Národnú radu, avšak bez účasti sociálnodemokratických poslancov a poslancov z vel'konemeckej strany (tzv. Rumpfparlament). Národná rada však paradoxne neprijala ústavu, ale schválila iba zmocňovací zákon, čiže spolkový ústavný zákon o mimoriadnych opatreniach týkajúcich sa ústavy (BGBl. 255/1934-I) ${ }^{13}$. Týmto zákonom parlament jednak zrušil čl. 44 ods. 2 BVG (čl. I.), takže ústava sa dala v celosti menit' bez toho, aby sa vyžadoval plebiscit. Parlament tiež splnomocnil vládu, aby uverejnila už raz uverejnenú ústavu (čl. II). Zákon sa tiež dotýkal rozpustenia Národnej rady a Spolkovej rady (čl. III. ods. 1) a napokon aj prechodu oprávnení Národnej rady a Spolkovej rady na spolkovú vládu a to aj v oblasti spolkového zákonodarstva

11 „Die Zeit des kapitalistischen Systems, die Zeit kapitalistisch-liberalistischer Wirtschaftsordnung ist vorüber, die Zeit marxistischer, materialistischer Volksverführung ist gewesen! Die Zeit der Parteienherrschaft ist vorbei! Wir lehnen Gleichschalterei und Terror ab, wir wollen den sozialen, christlichen, deutschen Staat Österreich auf ständischer Grundlage, unter starker, autoritäter Führung! Autorität heißt nicht Willkür. Autorität heißt geordnete Macht, heißt Führung durch verantwortungsbewusste, selbstlose, opferbereite Männer. "In: DOLLFUß, Engelbert. Trabrennplatzrede am 11. September 1933 [cit. 15. 8. 2017]. Dostupné z: https://austria-forum.org/af/Wissenssammlungen/ Symbole/Faschismus_-_die_Symbole/Trabrennplatzrede_1933

Text reči porovnaný so zvukovým záznamom: Die Trabrennplatzrede-Ansprache von Bundeskanzller Engelbert Dollfuß mit Prinzipienerklärung des autoritären Regimes am 11. September 1933. Dostupné z: https://www.oesterreich-am-wort.at/

12 Verordnung der Bundesregierung über die Verfassung des Bundesstaates Österreich.

13 Bundesverfassungsgesetz über außerordentliche Maßnahmen im Bereich der Verfassung. 
a schval’ovania ústavných zákonov (čl. III. ods. 2). Spolková vláda následne ústavu uverejnila druhý krát formou vyhlášky (BGBl. 1/1934-II). Ústava bola publikovaná 1. mája 1934, pričom tento deň sa slávil ako „deň nového Rakúska.“ V zmysle tradičného historického označovania rakúskych ústav sa tejto ústave preto hovorí aj májová ústava (Maiverfassung).

Profesor viedenskej univerzity Adolf Merkl objasňoval tento kuriózny spôsob prijatia ústavy tak, že zámerom tvorcov ústavy bolo urobit' zadost' dvom odlišným právno-politickým myšlienkam. Na jednej strane autoritatívnemu princípu, ktorý súvisel s mimoparlamentnou metódou schválenia ústavy. Na druhej strane však tiež princípu právnej kontinuity, ktorá sa dala dosiahnut' parlamentnou cestou a formou plebiscitu. Podl’a Merklovho názoru, by na prijatie ústavy postačoval ktorýkol’vek z uvedených spôsobov, ked’že oba sú prejavom autority, ktorá má moc na to, aby presadila svoju vôl'u. Merkl však zároveň vyjadril určité pochybnosti o legalite postupu, ktorým bola ústava vydaná. KWEG totiž neumožňoval menit' prostredníctvom nariadení ústavu, čo bolo aj dôvodom na prijatie zmocňovacieho zákona Národnou radou. Avšak aj samotný zmocňovací zákon prekračoval ústavné limity. Jeho prijatie totiž v podstate znamenalo celkovú zmenu ústavy, ked’že zákonodarné a ústavodarné kompetencie Národnej rady aj Spolkovej rady prenášal na vládu. Samotný zmocňovací zákon tak v zmysle čl. 44 ods. 2 BVG mal byt' predložený na l’udové hlasovanie, čo sa však nestalo. ${ }^{14}$ Napriek týmto logickým záverom sa však Merkl pravdepodobne z určitej opatrnosti poponáhl’al s uistením, že otázka kontinuity „nemôže samozrejme spochybnit’ záväznost' nového ústavného systému a povinnost' poslušnosti a vernosti podriadených subjektov voči novej štátnej autorite. "15

Okamih začiatku účinnosti ústavy mal v zmysle čl. 182 ods. 2 ústavy určit' spolkový ústavný zákon týkajúci sa prechodu k stavovskej ústave. Tento zákon z 19. júna 1934 označovaný tiež iba ako Verfassungsübergangsgesetz (BGBl. 75/1934-II) ${ }^{16}$ vykonal niekol'ko podstatných zmien v ústavnom systéme a odsunul úćinnost' viacerých ustanovení ústavy. Medzi takéto zmeny patrilo napríklad to, že členov Štátnej rady, Spolkovej hospodárskej rady a Spolkovej kultúrnej rady menoval prezident na návrh spolkového kancelára. Menovanie pritom pre svoju platnost' vyžadovalo kontrasignáciu spolkovým kancelárom, čo výrazne zvyšovalo vplyv spolkového kancelára na tieto orgány. Iným príkladom bolo toho, že v zmysle \ 28 bola prechodne zrušená garancia nezávislého súdnictva, ked’že sudcovia boli preložitel’ní a zosaditel'ní.

14 MERKL, Adolf. Die ständisch-autoritäre Verfassung Österreichs. Wien: Verlag von Julius Springer, 1935 , s. 9-12.

15 Das rechtswissenschaftliche Urteil in der Frage der Kontinuität des verfassunggebenden Aktes kann aber selbstverständlich nicht die Verbindlichkeit des neuen Verfassungsregimes und die Gehorsams- und Treuepflicht der Untertanen gegenüber der neuen Staatsautorität in Frage stellen. In: MERKL, Adolf. Die ständisch-autoritäre Verfassung Österreichs. Wien: Verlag von Julius Springer, 1935, s. 12.

16 Verfassungsgesetz betreffend den Übergang zur ständischen Verfassung. 
Vypracovanie samotnej ústavy mal na starosti krajinský náčelník spolkovej krajiny Voralbersko a minister bez kresla Otto Ender. Ústava pozostávajúca z preambuly a 182 článkov bola z legislatívno-technického hl'adiska urobená vynikajúco. Svojim jazykom bola rovnako výstižná a vecná ako BVG, vo svojej systematike však lepšia, pričom sa jej podarilo integrovat' takmer všetko ústavné právo. Osobitne to platí pre úpravu základných občianskych práv v čl. 15 až 33 ústavy, ktorá bola zaradená hned’ za základné ustanovenia, aby sa tak demonštrovalo, že existujú také práva, ktoré dal človeku Stvoritel’ a štáty ich preto musia rešpektovat'. ${ }^{17}$ Zaradenie katalógu základných práv a slobôd do ústavy, ktorá zjavne nebola demokratická pritom nebolo iba rakúske špecifikum, ale základné práva a slobody sa zaviazali v ústave rešpektovat' aj iné nedemokratické štáty, akými boli napríklad Slovenská republika či Portugalsko, ked’že aj oni, podobne ako Rakúsko odkazovali na krest’anskú náuku o prirodzenom práve. Okrem toho, integrácia katalógu základných práv a slobôd priamo do ústavného textu predstavovala v rakúskych reáliách vel'ký pokrok, ked'že napríklad BVG ponechal v platnosti celý rad zákonov zo šest'desiatych rokov 19. storočia, ktoré sa dotýkali základných občianskych práv.

Ústava na rozdiel od dovtedajších rakúskych ústav začínala preambulou. Preambulu bolo možné pokladat' za akési programové vyhlásenie obsahujúce základné princípy ústavy respektíve za akési výkladové pravidlo. ${ }^{18}$ „V mene Boha všemohúceho, od ketorého pochádza všetko právo obdržal rakúsky lud pre svoj krest'anský, nemecký, spolkový stát na stavouskom základe túto ústavu. "Preambula bola vo viacerých smeroch špecifická. Chýbala v nej zmienka o republikánskej forme vlády. Ústava sa totiž do určitej miery vracala do minulosti a odkazovala na habsburskú monarchiu. V zmysle čl. 3 ods. 2 ústavy sa tak dvojhlavá orlica s červeno-bielo-červeným štítom rodu Babenbergerovcov dostala opät' do štátneho znaku. ${ }^{19}$ Okrem monarchistických reminiscencií však bolo dôležitejšie, že pojem republika stelesňujúci povojnový vývoj bol opustený, aby sa zdôraznilo, že došlo ku klúčovým zmenám vo fungovaní štátu. ${ }^{20} \mathrm{Na}$ miesto pojmu „Rakúska republika“, sa tak začal používat’ názov „Spolkový štát Rakúsko“ (Bundestaat Österreich). Hoci Adolf Merkl

17 WIEDERIN, Ewald. Christliche Bundesstaatlichkeit auf ständischer Grundlage: Eine Strukturanalyse der Verfassung 1934. In: REITER-ZATLOUKAL, Ilse, Christiane ROTHLÄNDER a Pia SCHÖLNBERGER (Hg.). Österreich 1933-1938. Wien-Köln-Weimar: Bohlau Verlag, 2012, s. 39.

18 MERKL, Adolf. Die ständisch-autoritäre Verfassung Österreichs. Wien: Verlag von Julius Springer, 1935 , s. 143.

19 Súčast'ou BVG bol aj zákon týkajúci sa postúpenia pôdy a prevzatia majetku Habsbursko-Lotrinskej dynastie (StGB1. 209/1919). Tento zákon však verejnost' vnímala ako určitú formu nespravodlivosti, ked’že rakúsky štát si privlastnil majetok Habsburgovcov, pričom podl’a prevládajúcich názorov išlo o súkromný majetok členov cisárskej dynastie. Vo vládnucích kruhoch existovala ochota túto nespravodlivost' napravit', k čomu malo dopomôct' i to, že predmetný zákon stratil ústavnú povahu a mal d'alej charakter obyčajného zákona. In: ENDER, Otto. Die neue Österreichische Verfassung. Wien-Leipzig: Österreichischer Bundesverlag für Unterricht, Wissenschaft und Kunst, 1934, s. 30.

20 WIEDERIN, Ewald. Christliche Bundesstaatlichkeit auf ständischer Grundlage: Eine Strukturanalyse der Verfassung 1934. In: REITER-ZATLOUKAL, Ilse, Christiane ROTHLÄNDER a Pia SCHÖLNBERGER (Hg.). Österreich 1933-1938. Wien-Köln-Weimar: Bohlau Verlag, 2012, s. 32-33. 
zastával stanovisko, že ústava má republikánsky charakter, uviedol tiež, že zákonodarne kolégiá, ktoré ústava vytvorila ani podl’a ich zloženia ani podl’a ich pôsobnosti nemožno pokladat’ za parlamenty v zvyčajnom slova zmysle. ${ }^{21}$ Zastávam preto názor, že vyhýbanie sa pojmu republika v obdobných ústavách, ako bola napríklad už zmienená portugalská ústava nebolo náhodné. V Portugalsku sa pre označenie Salazarovho režimu používal pojem Nový štát (Estado Novo). Koniec-koncov aj v prípade Slovenskej republiky, ktorej ústava z roku 1939 síce používala pojem republika je zrejmé, že ústavný systém bol iba sčasti republikánsky a vo verejnom diskurze sa presadil skôr pojem Slovenský štát.

Historické a náboženské reminiscencie tak typické pre autoritatívne režimy sa odrazili aj v zmienke o krest'anskom charaktere štátu. Ústava pritom v rámci jednotlivých cirkví a náboženských spoločností dávala prednost' katolíckej cirkvi. Pozíciu katolíckej cirkvi stanovil konkordát z 5. júna 1933 medzi Svätou stolicou a Rakúskom (BGBl. 2/1934-II), pričom niektorým jeho ustanoveniam dala ústava $\mathrm{v}$ čl. 30 ods. 4 silu ústavných ustanovení. Znamenalo to, že štát a cirkev sa prepojili na podobnej báze ako za čias neoabsolutizmu v pät'desiatych rokoch 19 . storočia. ${ }^{22}$ Podl'a Merkla časti ústavy, kde sa bezprostredne prejavoval krest’anský princíp boli nielen ústavou recipované ustanovenia konkordátu, ale taktiež rámcové ustanovenia o stavovskej samospráve, ktorých vytvorenie predstavovalo realizáciu požiadavky katolíckeho prirodzeného práva. Hodnoty krest’anstva mali byt' taktiež smernicou pre tvorbu zákonov a celý štátny život. ${ }^{23}$

S ideovými základmi iných autoritatívnych ústav korešpondoval aj fakt, že ústava upustila od myšlienky, že všetko právo pochádza z l'udu. Podl'a Otta Endera existujú totiž také právne princípy, ktoré boli Stvoritel’om vložené do prirodzenosti človeka a na ktoré človek nemôže beztrestne nedbat' alebo ich vyvracat'. Práve v tomto zmysle potom pochádza všetko právo od Boha a úlohou l’udí je vytvorit' právny poriadok na tom základe, že uznajú a budú dodržiavat' tieto večné zákony. ${ }^{24}$

Pojem demokracia v preambule taktiež chýbal. Otto Ender k tomu uviedol, že Rakúsko bolo v BVG právom označené ako demokratický štát. Národná rada bola volená priamo plnoletými rakúskymi občanmi na základe pomerného zastúpenia. Parlamentný systém však viedol k vytvoreniu parlamentu, ktorý bol roztrieštený na politické strany. Ked’že parlament určoval zloženie vlády, aj vláda niesla silnú stranícku pečat’. Pomerný volebný systém spoločne s neefektívnym rokovacím poriadkom, ktorý sa nedokázal vzopriet' demagógii a obštrukciám zbavili podl'a Otta Endera parlament potrebnej efektivity

21 MERKL, Adolf. Die ständisch-autoritäre Verfassung Österreichs. Wien: Verlag von Julius Springer, 1935, s. 18-19.

22 BRAUNEDER, Wilhelm a Friedrich LACHMAYER. Österreichische Verfassungsgeschichte. Wien: Manzsche Verlag, 1989, s. 236.

23 MERKL, Adolf. Die ständisch-autoritäre Verfassung Österreichs. Wien: Verlag von Julius Springer, 1935, s. 15.

24 ENDER, Otto. Die neue Österreichische Verfassung. Wien-Leipzig: Österreichischer Bundesverlag für Unterricht, Wissenschaft und Kunst, 1934, s. 3. 
a mali negatívny dopad aj na vládu, ked’že tá nemohla včas presadit’ formou zákona potrebné opatrenia. Voči parlamentarizmu a straníckemu systému tak vznikla vel'ká nedôvera, čo výrazne ovplyvnilo a zjednodušilo prechod na autoritatívny systém vlády. ${ }^{25}$ Ústava však predsa len všetky demokratické princípy neopustila. Naznačuje to jednak spôsob publikácie ústavy, ked’že vláda ústavu po druhýkrát publikovala na základe zmocnenia, ktoré jej poskytol parlament. V ústave síce absentoval zákonodarný orgán vytvorený na základe všeobecného, rovného, priameho a tajného hlasovacieho práva, avšak zákonodarstvo ovplyvňovali určitou mierou aj stavy, ktoré by sa dali považovat’ za určitú formu reprezentácie l’udu, ako na to poukazujú Brauneder a Lachmayr. ${ }^{26}$ Okrem toho ústava umožňovala občanom priamo sa zapojit' do zákonodarného procesu prostredníctvom referenda, hoci iba na základe vládnej iniciatívy. Napokon, je zrejmé, že aj systematika ústavy do určitej miery nadväzovala na svoju demokratickú predchodkyňu z roku 1920 respektíve 1929. To je očividné napríklad v systematickom zaradení výkonnej moci až do piatej hlavy ústavy za zákonodarnú moc napriek tomu, že vláda predstavovala v podstate najvýznamnejší štátny orgán.

Termín autoritatívny preambula síce priamo nepoužívala, no podl'a Adolfa Merkla tento pojem ako znak ústavy bolo možné nepriamo vyvodit’ zo slovného spojenia použitého v preambule ,obdř̌al rakúsky l’ud... túto ústavu. "Ústava tak bola oktrojovaná podobne ako marcová ústava z roku 1849 alebo februárový patent z roku 1861. ${ }^{27}$ Došlo k narušeniu systému del'by mocí, ked’že vláda sa začala v rozhodujúcej miere podiel’at' na zákonodarnej moci a jednotlivé zákonodarné orgány mali v podstate iba druhoradú úlohu. Dovtedajší volebný systém bol nahradený menovaním prípadne výberom zo zostavených kandidátnych listín. Komentátori rakúskej ústavy sa však na druhej strane dištancovali od totalitarizmu, čo zodpovedalo odmietavému postoju rakúskych vládnych kruhov voči nacistickému Nemecku. Podl'a A. Merkla zamieňanie štátu so spoločnost'ou, všemohúcnost' štátu a bezvýznamnost' jedinca sú v ústave vylúčené a to v dôsledku krest'anského, stavovského či spolkového princípu, ktorých aplikácia si vyžaduje určitú mieru autonómie cirkví, náboženských spoločností či stavovských korporácií, ako aj v dôsledku zakotvenia l’udských a občianskych práv do ústavy. ${ }^{28}$

25 ENDER, Otto. Die neue Österreichische Verfassung. Wien-Leipzig: Österreichischer Bundesverlag für Unterricht, Wissenschaft und Kunst, 1934, s. 4.

26 BRAUNEDER, Wilhelm a Friedrich LACHMAYER. Österreichische Verfassungsgeschichte. Wien: Manzsche Verlag, 1989, s. 237.

27 MERKL, Adolf. Die ständisch-autoritäre Verfassung Österreichs. Wien: Verlag von Julius Springer, 1935 , s. $15-16$.

28 Ibid., s. 152-153. 


\section{Pomer medzi zákonodarnou a výkonnou mocou ako autoritatívne špecifikum ústavy}

Ako som už uviedol, najdominantnejším princípom rakúskej ústavy bol autoritatívny princíp. Jeho využite v ústave znamenalo na jednej strane úplnú premenu koncepcie zákonodarnej moci spojenú s odstránením všeobecného volebného práva a systému politických strán. Zavedenie autoritatívneho systému znamenalo však tiež výrazné posilnenie výkonnej moci. Hoci preambula rakúsky štát charakterizovala ako stavovský a spolkový, podl'a Adolfa Merkla dostali tieto princípy v ústave priestor iba do tej miery, aby nespochybnili hlavný ústavný princíp, čiže autoritatívne riadenie štátu. ${ }^{29}$

Zákonodarný proces sa opieral o tri základné myšlienky. V zákonodarnej činnosti sa mali uplatnit' stavy, d'alej sa do nej mali zapojit' aj krajiny a napokon pri koncipovaní orgánov zákonodarnej moci sa malo dbat' aj na konzervatívny prvok, ktorý mala predstavovat' Štátna rada, ktorá z hl'adiska rakúskej ústavnej histórie zodpovedala niekdajšej panskej snemovni. ${ }^{30}$ Zákonodarnú iniciatívu mala však výhradne spolková vláda. Vládny návrh zákona bol postúpený príslušným poradným orgánom, avšak o jeho schválení rozhodoval až Spolkový snem (Bundestag). Poradné orgány teda vládny návrh zákona neschval’ovali, ale ich úlohou bolo iba zaujatie odborného stanoviska a navrhnutie prípadných zmien pred tým, ako bol návrh postúpený Spolkovému snemu na schválenie. Medzi tieto poradné orgány patrila Štátna rada (Staatsrat), Spolková kultúrna rada (Bundeskulturrat), Spolková hospodárska rada (Bundeswirtschaftsrat) a napokon Krajinská rada (Länderrat).

Úlohou Spolkovej hospodárskej rady bolo posudzovat' vládne návrhy zákonov z hl'adiska hospodárskych záujmov. V Spolkovej hospodárskej rade sa mal prejavovat' stavovský princíp, ked’že jej členov, ktorých malo byt' podl'a ústavy od 70 do 80 mali vysielat' jednotlivé stavy. V zmysle čl. 48 ods. 4 ústavy mali členovia rady reprezentovat' pol'nohospodársky stav, priemysel a baníctvo, živnostenský stav, obchod a dopravu, peňažníctvo a poist'ovníctvo a napokon tiež slobodné povolania a verejnú službu. Zatial čo Spolková hospodárska rada posudzovala vládny návrh zákona z hospodárskeho pohl'adu, úlohu Spolkovej kultúrnej rady bolo podávat' odborné stanoviská z hl’adiska kultúrno-spoločenských záujmov. Spolková hospodárska rada sa kreovala zo stavov, ktoré mali hospodársku povahu. Naproti tomu, Spolková kultúrna rada pozostávala z 30 až 40 zástupcov korporácií, ktoré mali kultúrno-spoločenský význam. Jej členmi mali byt’ zástupcovia cirkví a náboženských spoločností uznaných zákonom, d’alej zástupcovia školstva, výchovných a vzdelávacích inštitúcií a tiež vedy a umenia. Ústava na tomto mieste nasledovala konzervatívne medzivojnové autoritatívne režimy, akým bolo napríklad Portugalsko

29 MERKL, Adolf. Die ständisch-autoritäre Verfassung Österreichs. Wien: Verlag von Julius Springer, 1935, s. 13.

30 ENDER, Otto. Die neue Österreichische Verfassung. Wien-Leipzig: Österreichischer Bundesverlag für Unterricht, Wissenschaft und Kunst, 1934, s. 10. 
a podobne ako portugalský ústavný text zvýraznila význam rodiny. V čl. 47 ods. 3 totiž výslovne ustanovila, že v zložení Spolkovej kultúrnej rady sa má v rámci zastúpenia výchovných inštitúcií brat' zretel' aj na rodičovstvo, avšak v tradičnom slova zmysle, ked’že podl’a Otta Endera sa tu mali na mysli rodičia manželských detí, s ktorými žili v jednej domácnosti. ${ }^{31}$

Obe rady mali predstavovat' realizáciu v danej dobe tak často propagovaného korporatívneho či stavovského systému. Teda nielen hospodárske stavy (Berufstände), ale aj predstavitelia kultúrno-spoločenských kruhov (Kulturgemeinschaften) vytvárali zložky stavovskej organizácie spoločnosti tak, ako bola prezentovaná v pápežskej encyklike Quadragesimo Anno z 15. mája 1931. ${ }^{32}$ Ústava však, pokial' ide o ich organizáciu ponechala viaceré otázky otvorené. Ústava síce tak v prípade Spolkovej kultúrnej rady a Spolkovej hospodárskej rady trochu pateticky ustanovovala, že ich členmi majú byt' vlastenci (vaterlandstreue Mitgliedern), no presnú úpravu zloženia Spolkovej kultúrnej rady ponechala obyčajnému zákonu. V prípade Spolkovej hospodárskej rady ústava uvádzala, že prerozdelenie jednotlivých mandátov v rade na jednotlivé základné stavovské skupiny má byt' úmerné počtu príslušníkov jednotlivých povolaní, pričom každé hlavné stavovské zoskupenie v rade má mat' aspoň troch členov. Aj v tomto prípade ústava odkazovala na vydanie obyčajného zákona, ktorý by podrobnejšie upravil obsadzovanie rady členmi jednotlivých stavov. Spôsob prerozdelenia mandátov na jednotlivé povolania v rámci stavovských skupín však mohol byt’ značne problematickou úlohou. Zásada, že jednotlivé povolania mali byt' zastúpené podl'a ich spoločenského významu, ktorá sa často opakovala v literatúre venujúcej sa stavovskému systému vychádzala podl’a Adolfa Merkla z nedostatku objektívne platnej a uznávanej miery spoločenského významu daného povolania. Všetky skúsenosti so stavovskými zastupitel'skými orgánmi ako bola napríklad pruská národohospodárska rada z roku 1880 alebo ríšska hospodárska rada z roku 1919 ukázali, že medzi jednotlivými povolaniami existujú neprekonatel’né názorové rozdiely o ich hospodárskom význame. $\mathrm{V}$ rámci jednotlivých hlavných stavovských skupín by sa pritom mohli medzi zástupcami jednotlivých povolaní (napríklad priemysel a baníctvo, obchod a doprava) vyskytnút' často neodstránitel'né názorové rozpory, ktoré by bránili dosiahnutiu konsenzu. ${ }^{33}$

Úlohou krajinskej rady bolo pri posudzovaní vládnych návrhov zákonov reprezentovat' záujmy jednotlivých spolkových krajín. Ani v tomto prípade sa na kreácii krajinskej rady nepodiel’ali priamo občania vzhl'adom na to, že v zmysle čl. 49 ods. 1 každá krajina

31 ENDER, Otto. Die neue Österreichische Verfassung. Wien-Leipzig: Österreichischer Bundesverlag für Unterricht, Wissenschaft und Kunst, 1934, s. 10.

32 MERKL, Adolf. Die ständisch-autoritäre Verfassung Österreichs. Wien: Verlag von Julius Springer, 1935 , s. 147.

33 Porovnaj: MERKL, Adolf. Die ständisch-autoritäre Verfassung Österreichs. Wien: Verlag von Julius Springer, 1935, s. 68-69. 
vysielala do rady vždy krajinského náčelníka a toho člena krajinskej vlády, ktorý mal na starosti financie.

Posledným a najvýznamnejším konzultatívnym orgánom bola Štátna rada. Tá, podobne ako ostatné orgány, ktoré sa podiel’ali na zákonodarnej činnosti, nebola priamo volená. Mala mat' od 40 do 50 členov, ktorých menoval spolkový prezident, čo si však vyžadovalo kontrasignáciu spolkovým kancelárom (čl. 46 ods. 1 a 2). Úlohou Štátnej rady bolo posúdit', či predložený návrh zákona zodpovedal požiadavkám, ktoré vyžadovala štátna zvrchovanost', všeobecné blaho a tiež efektívna aplikácia zákona v praxi. Štátna rada sa tak mala zaoberat' právno-politickými problémami a taktiež otázkami redakcie/vydávania zákonov. Povolanie odborníkov na legislatívno-technickú prax do Štátnej rady malo zvýšit' legislatívno-technickú úroveň zákonov, ktorá podl’a Merkla vel'mi poklesla počas parlamentarizmu. ${ }^{34}$ Vzhl'adom na svoje zloženie predstavovala Štátna rada obdobu panskej snemovne z čias monarchie. V panskej snemovni zasadali aj členovia, ktorým toto privilégium prepožičal cisár na obdobie ich života za zásluhy o štát, cirkev, vedu a umenie. V prípade Štátnej rady bolo právom prezidenta vybrat’ jej členov, pričom to mali byt' zaslúžilí, charakterní občania, od ktorých bolo možné na základe ich doterajšieho správania a zásluh očakávat' pochopenie potrieb a úloh štátu. (čl. 46 ods. 1). $\mathrm{Na}$ rozdiel od panskej snemovne však podmienkou členstva nebola ani tak intelektuálna kvalifikácia ako skôr určitá úroveň zmýšl’ania kandidátov. ${ }^{35}$

K vládnym návrhom zákonov v zmysle čl. 61 ods. 2 ústavy bola povinná vydat' stanovisko iba Štátna rada. Spolkovej kultúrnej rady sa táto povinnost' dotýkala iba v prípade, ked’ spolková vláda jednotlivé návrhy označila za úplne či prevažne kultúrneho významu. To isté platilo i pre Spolkovú hospodársku radu. Poradné orgány, ktorých sa povinnost' vydat' stanovisko k návrhu netýkala, mohli stanovisko vydat' dobrovol’ne.

Jednotlivé rokovania poradných orgánov mali neverejný charakter, ked’že výsledkom ich činnosti malo byt' kvalitné odborné posúdenie vládneho návrhu zákona. Zásada verejnosti by podl'a Otta Endera mohla totiž prispiet' k tomu, že by odborné posúdenie mohla ovplyvnit' demagógia. Ústava taktiež poradným orgánom nedala právo interpelácie či zákonodárnej iniciatívy, ked’že tvorcovia ústavy boli presvedčení o neblahom vplyve týchto oprávnení v starom parlamente na jeho funkčnost' a efektívnost' a tak aj na to, ako na parlament nazerala verejnost'. Napokon aj v prípade poslaneckej imunity zastávali autori ústavy stanovisko, že bola v minulosti poslancami opakovane zneužívaná. Ako však konštatoval Otto Ender, ústava v tomto smere upadla do opačného extrému, ked’e inštitút poslaneckej imunity úplne odstránila. ${ }^{36}$

\footnotetext{
34 MERKL, Adolf. Die ständisch-autoritäre Verfassung Österreichs. Wien: Verlag von Julius Springer, 1935 , s. 75.

35 Ibid., s. 63.

36 ENDER, Otto. Die neue Österreichische Verfassung. Wien-Leipzig: Österreichischer Bundesverlag für Unterricht, Wissenschaft und Kunst, 1934, s. 11-12.
} 
Spolkový snem (Bundestag) bol tradičným zákonodarnym orgánom iba v určitom zmysle. V zmysle čl. 50 ods. 1 ústavy pozostával z 20 poslancov Štátnej rady, 10 poslancov Spolkovej kultúrnej rady, 20 poslancov Spolkovej hospodárskej rady a 9 členov Krajinskej rady. Jednotliví členovia Spolkového snemu, s výnimkou členov zastupujúcich krajinskú radu boli volení nepriamou formou jednotlivými radami. Ani v prípade Spolkového snemu teda nemožno hovorit' o aplikácii tradičného všeobecného hlasovacieho práva. Okrem toho, jeho úlohou bolo bud' schválit' alebo neschválit' vládne návrhy zákonov bez toho, aby o návrhu zákona prebehla akákol'vek diskusia. Spolkový snem nielenže v zásade nemal vplyv na obsah schval’ovaných vládnych návrhov zákonov, ale nemal ani právo zákonodarnej iniciatívy, ktorým disponovala výhradne spolková vláda.

Dôvod, prečo sa v Spolkovom sneme o návrhu zákona nerokovalo spočíval v tom, že členovia Spolkového snemu vlastne už vládny návrh zákona odborne posúdili v jednotlivých poradných orgánoch. Vláda však mohla návrh zákona Spolkovému snemu predložit' na schválenie aj bez toho, aby prihliadla na jednotlivé odborné stanoviská poradných orgánov. ${ }^{37}$ Spolkový snem sa mal na vládnom návrhu zákona uzniest' respektíve ho odmietnut' vo vládou stanovenej lehote (čl. 62 ods. 2) pričom spolková vláda mohla kedykol'vek pred hlasovaním návrh zákona stiahnut' alebo v ňom urobit' také zmeny, „ktoré sa vz̧hladom na svoje znenie nedotýkali podstaty návrhu“ (čl. 62 ods. 4).

Vláda mala výhradne právo zákonodarnej iniciatívy. Nemusela dbat’ na odborné stanoviská jednotlivých poradných orgánov, pričom ústava jej dokonca v čl. 65 umožňovala pohodlne obíst' aj Spolkový snem. Pokial’ totiž Spolkový snem odmietol vládny návrh zákona, vláda ho prostredníctvom spolkového prezidenta mohla predložit' na l'udové hlasovanie. Ak sa občania v hlasovaní vyslovili za návrh, takto schválený návrh zákona bol ihned' vyhlásený. ${ }^{38}$

Postavenie výkonnej moci bolo v ústave zakotvené v piatej hlave, pričom výkonnú moc predstavoval prezident a spolková vláda.

Pokial ide o postavenie spolkového prezidenta, ústava v zmysle čl. 73 ods. 1 zakotvovala celkom nový spôsob obsadzovania prezidentskej funkcie, ked’že spolkového prezidenta mali volit' starostovia jednotlivých rakúskych obcí na základe návrhu troch kandidátov, ktorý vypracovalo Spolkové zhromaždenie (Bundesversammlung), ktoré sa na tento účel vytvorilo zo zástupcov jednotlivých zákonodarnych orgánov. Uvedený spôsob kreácie prezidentskej funkcie v praxi nebol použitý a funkčné obdobie úradujúceho prezidenta Wilhelma Miklasa bolo VUG z roku 1934 predížené. Vlastné kompetencie prezidenta, kooperácia so spolkovou vládou, predíženie funkčného obdobia na 7 rokov a novo zavedená nezodpovednost', to všetko vzbudzovalo dojem, že význam jeho funkcie narástol.

37 BRAUNEDER, Wilhelm a Friedrich LACHMAYER. Österreichische Verfassungsgeschichte. Wien: Manzsche Verlag, 1989, s. 240.

38 K celkovému priebehu zákonodarného procesu na spolkovej úrovni pozri aj: TÁLOS, Emmerich. Das austrofaschistische Herrschaftssystem. Österreich 1933-1938. 2. vyd. Münster: LIT Verlag, 2013, s. 95-96. 
Práve nezodpovednost' za výkon svojho úradu mala byt' podl'a A. Merkla znakom prednosti prezidentskej funkcie pred všetkým orgánmi a obzvlášt' pred vládou. ${ }^{39}$ Pravdou bol však skôr opak a význam spolkového prezidenta sa znižoval v protiklade k nárastu významu spolkovej vlády. ${ }^{40}$

Pokial' ide o spolkovú vládu, na jej menovaní spolkovým prezidentom či na jej funkcii najvyššieho výkonného orgánu v štáte nenastali žiadne podstatné zmeny. Ústava však podstatne zasiahla do jej štruktúry. Zatial čo v dovtedajšom rakúskom ústavnom systéme bola vláda tradične chápaná ako kolegiálny orgán, čo znamenalo, že jednotliví ministri boli vzájomne postavení na rovnakú úroveň a spolkový kancelár mal iba postavenie „primus inter pares“, nová ústava v čl. 81 ods. 1 ustanovila, že vládu tvoria jednotliví ministri pod vedením spolkového kancelára. ${ }^{41}$ Práve použitie termínu vedenie (Führung) namiesto pojmu predsedníctvo (Vorsitz) bolo podl’a A. Merkla prejavom aplikácie vodcovského princípu na vnútornú organizáciu vlády. Znamenalo to, že spolkový kancelár a jednotliví ministri prestali byt' kolegami a vznikol medzi nimi vzt'ah podriadenosti a nadriadenosti. Adolf Merkl však na druhej strane poukázal aj na to, že ústava v čl. 93 ustanovovala, že spolkový kancelár síce určuje smernice politiky, avšak v rámci nich mal riadit' každý spolkový minister svoj rezort samostatne. Okrem toho, z čl. 94 ústavy, v ktorom sa hovorí o poradách spolkovej vlády a jej uzneseniach, vyplývalo, že kolegiálny princíp by sa vo vláde v určitých prípadoch mohol zachovat'. Podl'a Merkla tak bolo možné domnievat' sa, že ústava prenesením vodcovskej úlohy na spolkového kancelára nezmenila kolegiálnu povahu vlády, ale iba brala ohl’ad na terminológiu panujúcej politickej ideológie. ${ }^{42}$

V novej ústave sa vláda stala tiež nositel'kou časti zákonodarnej moci. Presun časti zákonodarnej moci na vládu formou takzvaného zmocňovacieho zákonodarstva nebol typický iba pre nedemokratické režimy, ale v medzivojnovom období sa vyskytoval aj v demokratických štátoch, akými bola napríklad Vel'ká Británia (Defence of the Realm Act z roku 1914 alebo Emergency Power Act z roku 1920) či Francúzsko (zmocnenie pre Poincarého či Lavalovu vládu v dvadsiatych a tridsiatych rokoch). Zatial čo však v parlamentných demokraciách boli zmocnenia skôr dočasným javom, ktorý bol motivovaný hospodársky, ekonomicky či vojensky, v autoritatívnych štátoch sa delegácia zákonodarnej moci na vládu stala trvalou súčast'ou ústavného systému.

V medzivojnovom Rakúsku mal takýto hospodársky účel napríklad už spomínaný KWEG z roku 1917, pričom išlo o zmocňovací zákon schválený parlamentom. Monopol

\footnotetext{
39 MERKL, Adolf. Die ständisch-autoritäre Verfassung Österreichs. Wien: Verlag von Julius Springer, 1935, s. 85.

40 BRAUNEDER, Wilhelm a Friedrich LACHMAYER. Österreichische Verfassungsgeschichte. Wien: Manzsche Verlag, 1989, s. 241.

41 „Sie bilden in ibrer Gesamtheit die Bundesregierung unter Führung des Bundeskanqlers. “

42 MERKL, Adolf. Die ständisch-autoritäre Verfassung Österreichs. Wien: Verlag von Julius Springer, 1935, s. 86-87.
} 
parlamentu v oblasti zákonodarnej moci bol však narušený až novelou BVG z roku 1929, ktorá dala prezidentovi právomoc na vydávanie nariadení spolkového prezidenta ako formy takzvaného núdzového zákonodarstva. Nová rakúska ústava pokračovala v nastúpenom trende, avšak s tým, že z mimoriadneho prostriedku umožňujúceho vláde vydávat’ nariadenia s mocou zákona, ktorý však vždy závisel od zmocnenia zo strany parlamentu, sa stala riadna právomoc vlády. V desiatej hlave ústavy sa nachádzala osobitná úprava takzvaných núdzových oprávnení výkonnej moci (Notrechte der Verwaltung). Na rozdiel od právomoci vlády obíst’ zákonodarné orgány tak, že o vládnom návrhu zákona nechala hlasovat' v plebiscite (čl. 65), vlastné núdzové opatrenia umožňovali, aby spolková vláda, ale v niektorých prípadoch aj spolkový prezident suplovali úlohu spolkového snemu. ${ }^{43}$

Základným ustanovením ústavy, ktoré na rakúsku vládu permanentne prenieslo rozsiahlu čast’ zákonodarnej moci bol čl. 147 ústavy. Išlo o ustanovenie, ktoré vláde umožnilo vydávat' núdzové nariadenia spolkovej vlády (Notverordungen der Bundesregierung), a ktorého obdoby sa vyskytovali aj v iných autoritatívnych ústavách. Ústava portugalského Nového štátu z roku 1933 preniesla na vládu právo vydávat’ dekréty s mocou zákona a to bud' na základe zákonného zmocnenia parlamentom alebo aj bez takéhoto zmocnenia $\mathrm{v}$ naliehavých prípadoch a v stave núdze a za rovnakých predpokladov aj schval’ovat' medzinárodné dohovory a zmluvy (čl. 109 ods. 2 portugalskej ústavy). S predmetným článkom rakúskej ústavy korešpondoval aj \44 ústavy Slovenskej republiky z roku 1939, ked’že i ten umožňoval, aby bola vláda subsidiárnym nositel'om časti zákonodarnej moci. ${ }^{44} \mathrm{~V}$ tomto prípade si obe ustanovenia boli blízke aj svojou textovou formuláciou čo by nasvedčovalo tomu, že autori o čosi mladšej slovenskej ústavy čerpali priamo z rakúskej predlohy. ${ }^{45}$ Rakúska ústava zakotvila v čl. 147, že ,ak. je na zachovanie verejnej bezpečnosti, poriadku, na zabezperenie dôležitých hospodárskych záujmov obyvatel'stva alebo finančných záujmov spolku, obzvlást' na zabezpečenie spolkovébo rozpočtu potrebné vydanie neodkladných opatreni, na ktoré sa z hl'adiska ústavy vyžaduje uznesenie spolkového snemu, ktoré ale vahl'adom na existujuce pomery nemožno očakávat', môžze spolková vláda na vlastnú zodpovednost' uskutočnit' tieto opatrenia dočasnými nariadeniami s mocou zákona. "46

43 MERKL, Adolf. Die ständisch-autoritäre Verfassung Österreichs. Wien: Verlag von Julius Springer, 1935, s. $107-108$.

44 GALBAVÝ, Tibor. Naša ústava a legislatívna prax. In: Právny obzor, 1939, roč. 22, s. 229.

45 Paragraf 44 slovenskej ústavy uvádzal, že ak na zamedzenie nenahraditel’nej ujmy vážne hospodárske, finančné alebo politické záujmy štátu vyžadujú neodkladné opatrenia, vláda ich môže vydat' nariadením s mocou zákona s výnimkou vecí, ktoré patria do výlučnej právomoci Snemu, alebo ktoré podl’a ústavy má upravit' zákon.

46 „Wenn zur Aufrechterhaltung der öffentlichen Sicherbeit und Ordnung, zur Wabrung wichtiger wirtschaftlicher Interessen der Bevölkerung oder staatsfinanzieller Interessen des Bundes, insbesondere zur Sicherung des Bundeshaushaltes, die sofortige Erlassung von Maßnahmen, die verfassungsmäßig der Beschlußfassung des Bundestages bedürfen, notwendig wird, sofortige Beschlußfassung des Bundestages aber nach den gegebenen Verbältnissen nicht zu erwarten ist, kann die Bundesregierung unter ihrer Verantwortlichkeit diese Maßnahmen durch vorläufige gesetzändernde Verordnungen treffen. " 
Podl'a Adolfa Merkla prijatiu uznesenia zo strany Spolkového snemu vlastne nemusela bránit' žiadna objektívna prekážka, Spolkový snem sa mohol dokonca aj zhromaždit' za účelom prijatia uznesenia, avšak vláda mohla Spolkový snem obíst' a vydat' nariadenie s mocou zákona. Mohla tak urobit' napríklad vtedy, ak nemohla počítat' s urýchleným uznesením snemu v dôsledku opozičnej pozície Spolkového snemu voči vláde. ${ }^{47}$ Predmetné ustanovenie okrem toho obsahovalo značne vágne pojmy ako verejná bezpečnost' či zabezpečenie dôležitých hospodárskych záujmov, ktorých výklad podl’a môjho názoru závisel predovšetkým od spolkovej vlády, na základe čoho sa možno domnievat', že by bol v praxi značne účelový. Pravdepodobne preto, aby nedošlo k prebujneniu vládnych nariadení s mocou zákona $\mathrm{v}$ rakúskom právnom poriadku, ${ }^{48}$ ústava zakotvovala aj určité ústavné brzdy. Tento systém bŕzd však bol nedostatočný. Nariadenie spolkovej vlády tak malo byt' bezodkladne postúpené Spolkovému snemu, ktorý sa v zmysle čl. 147 ods. 5 ústavy mohol uzniest' na tom, že požaduje jeho zrušenie, čo malo za následok zrušenie vládneho nariadenia a nadobudnutie účinností tých zákonných ustanovení, ktoré boli nariadením dotknuté. Účinnost' tejto kontroly zo strany Spolkového snemu však znižovalo to, že ústava vyžadovala kvórum aspoň polovice členov Spolkového snemu, pričom za zrušenie museli hlasovat' aspoň dve tretiny členov Spolkového snemu. Členmi Spolkového snemu boli pritom osoby, od ktorých sa dala očakávat' lojalita voči vláde. Iným príkladom je to, že hoci čl. 147 ods. 6 ústavy ohraničoval platnost’ jednotlivých nariadení vlády na tri roky, nariadenie, ktoré po troch rokoch stratilo platnost' mohlo byt' opät' vydané v prípade, že existovali zákonné predpoklady na jeho vydanie. Rozsah pôsobnosti vlády však bol výrazne limitovaný tým, že v zmysle čl. 147 ods. 2 predmetnými nariadeniami nemohla menit' ústavu. Takouto právomocou však disponoval spolkový prezident.

Núdzové nariadenia spolkového prezidenta v zmysle čl. 148 ústavy (Notverordnungen des Bundespräsidenten) boli d'alšou formou núdzových oprávnení výkonnej moci. Ak hrozilo štátu alebo nejakej jeho časti bezprostredné nebezpečenstvo, ktorého odvrátenie nebolo možné dosiahnut' okamžitým uznesením Spolkového snemu a ani prostredníctvom núdzového nariadenia spolkovej vlády, na návrh vlády mohol spolkový prezident vydat' dočasné núdzové nariadenie spolkového prezidenta s mocou zákona. Na rozdiel od núdzových nariadení vlády, núdzové nariadenia spolkového prezidenta mohli pozmenit' aj jednotlivé ustanovenia ústavy, avšak nemohli pozmenit' ústavu ako celok alebo spôsobit' zmenu štátnej formy. ${ }^{49}$ Nariadenia spolkového prezidenta sa nemohli týkat' ani formy štátu a nesmeli obsahovat’ ani také ustanovenia, ktoré by sa dotýkali príslušnosti

47 MERKL, Adolf. Die ständisch-autoritäre Verfassung Österreichs. Wien: Verlag von Julius Springer, 1935, s. 108

48 ENDER, Otto. Die neue Österreichische Verfassung. Wien-Leipzig: Österreichischer Bundesverlag für Unterricht, Wissenschaft und Kunst, 1934, s. 25.

49 BRAUNEDER, Wilhelm a Friedrich LACHMAYER. Österreichische Verfassungsgeschichte. Wien: Manzsche Verlag, 1989, s. 240-241. 
Spolkového súdneho dvora preskúmavat' zákony a nariadenia alebo by túto jeho právomoc obmedzovali.

Ako sme si uviedli, ústava v čl. 62 ods. 2 ukladala vláde ustanovit’ lehotu pre uznesenie Spolkového snemu. Ak by nastala situácia, že Spolkový snem by sa vo vládou stanovenej lehote neuzniesol na schválení či zamietnutí návrhu zákona, ústava v čl. 148 ods. 6 oprávňovala spolkového prezidenta, aby na návrh spolkovej vlády vydal v návrhu obsiahnuté ustanovenia ako nariadenie. Autori ústavy tu úplne ignorovali Spolkový snem, ked’že takéto nariadenia nepodliehali ani kontrolnému oprávneniu Spolkového snemu a ani nestrácali platnost' po uplynutí troch rokov, ako to bolo v prípade núdzových nariadení spolkovej vlády.

Napokon je potrebné poukázat' aj na čl. III. ods. 2 spolkového ústavného zákona o mimoriadnych opatreniach týkajúcich sa ústavy, ktorý ostal platný aj po prijatí ústavy. Tento zákon vláde umožnil, aby vydávala zákony ako aj ústavné zákony, a to bez obmedzení, ktoré predpokladala ústava. Posúdenie, či sa má obíst’ ústavou predpokladaný zákonodarný proces a využit' zmocnenie podl’a čl. III. ods.2 citovaného ústavného zákona pritom záležalo iba na vláde. Spojenie ústavodarnej moci spolu so zákonodarnou mocou a výkonnou mocou $v$ rukách vlády tak z vlády urobilo nie najvyšší orgán výkonnej moci, ale najvyšší štátny orgán. ${ }^{50}$

\section{Záver}

Kríza parlamentnej demokracie, ktorá medzi dvoma svetovými vojnami postihla viaceré európske štáty zasiahla začiatkom tridsiatych rokov 20. storočia aj Rakúsko. Spolková vláda pod vedením spolkového kancelára Engelberta Dollfußa zabezpečila viacerými opatreniami, ktoré boli namierené voči parlamentu, politickým stranám a ústavnému súdu, postupné znefunkčnenie demokratickej formy vlády a začala budovat' konzervatívny autoritatívny režim. Ideové základy tohto režimu prezentoval spolkový kancelár vo svojej reči na viedenskom dostihovom okruhu Trabrennplatz. Vychádzajúc z hlbokej nedôvery voči systému parlamentnej demokracie ako ju koncipovala ústava z roku 1920 a straníckemu systému kancelár deklaroval, že nový režim má byt' okrem iného postavený na krest’anskom, stavovskom a autoritatívnom základe. Nový rakúsky režim sa podobne ako iné autoritatívne štáty dištancoval od modernistických totalitných ideológií a čerpal skôr z konzervatívnych hodnôt, akými boli rodina, stav, cirkev či autorita. Tieto základné ideové piliere boli následne inkorporované aj do novej rakúskej ústavy z mája 1934.

Z jednotlivých ideových základov novej rakúskej ústavy, bol zd’aleka najpodstatnejší autoritatívny princíp, hoci preambula ústavy ho na rozdiel od ostatných princípov zmieňovala iba nepriamo. Jeho podstata spočívala v zmene spôsobu obsadzovania

50 MERKL, Adolf. Die ständisch-autoritäre Verfassung Österreichs. Wien: Verlag von Julius Springer, 1935, s. 150. 
jednotlivých štátnych orgánov, ale predovšetkým v značnom posilnení výkonnej moci v neprospech moci zákonodarnej. Právo zákonodarnej iniciatívy dávala ústava výhradne spolkovej vláde. Vládny návrh zákona následne mal byt' podl'a jeho povahy odborne posúdený niektorým zo štyroch poradných orgánov, ktoré mali reprezentovat' záujmy konzervatívnyych prvkov rakúskej spoločnosti, záujmy krajín, ale tiež záujmy jednotlivých stavov. Až po takomto odbornom posúdení mal byt’ návrh zákona predložený Spolkovému snemu. Ten však nebol parlamentom v tradičnom slova zmysle, ked’že bol tvorený zástupcami jednotlivých poradných orgánov a bol teda kreovaný nepriamo. Ústava s niekol'kými výnimkami nepripúšt'ala, aby Spolkový snem o vládnych návrhoch zákonov diskutoval respektíve, aby k vládnym návrhom zákonov prijal vlastné pozmeňujúce návrhy. Spolkový snem sa tak mohol uzniest' iba na schválení alebo zamietnutí vládneho návrhu zákona. Pánom situácie bola pritom v zásade spolková vláda pod vedením spolkového kancelára. Spolková vláda totiž vôbec nemusela dbat' na odborné stanoviská jednotlivých poradných orgánov a koniec koncov ani na zamietavé uznesenie Spolkového snemu, ked’že schválenie návrhu zákona mohla dosiahnut' prostredníctvom l’udového hlasovania. Zákonodarná moc tak mala v ústavnom systéme iba druhoradú úlohu. Koniec-koncov ústava nevychádzala z princípu suverenity l’udu a úplne sa vyhla nielen pojmu demokracia, ale takisto aj pojmu republika. Výraz republika bol z ideologických dôvodov podobne ako v prípade Portugalska (Nový štát) nahradený pojmom Spolkový štát Rakúsko. Záver o degradácii zákonodarnej moci zvýrazňuje i to, že spolková vláda sa stala popri Spolkovom sneme nositel’kou časti zákonodarnej moci. V zmysle čl. 147 ods. 1 ústavy získala spolková vláda právomoc vydávat' núdzové nariadenia, ktorými mohla menit’ obyčajné zákony. Išlo pritom o vel'mi flexibilné ustanovenie, ktorého výklad vlastne závisel predovšetkým od samotnej vlády. Hoci sa zmocnenia vlády na vydávanie nariadení s mocou zákona vyskytovali aj v ústavných systémoch demokratických štátov, išlo o právomoc, ktorá vždy závisela od zmocnenia zákonodarným orgánom. Autoritatívne ústavy však takúto právomoc na vládu preniesli natrvalo a urobili ju nezávislou alebo takmer nezávislou od zákonodarnej moci. Prenesenie časti zákonodarnej moci na vládu predstavovalo jednu z najpodstatnejších charakteristických čŕt autoritatívych ústav. Obdobu citovaného ustanovenia rakúskej ústavy nájdeme totiž i v \ 109 portugalskej ústavy z roku 1933, ale taktiež aj v \44 ústavy Slovenskej republiky z roku 1939. Vzhl’adom na značnú textovú podobu medzi \44 ústavy Slovenskej republiky a \ 147 ods. 1 rakúskej ústavy sa možno domnievat', že práve rakúska ústava bola priamou predlohou pre znenie $\int 44$ slovenskej ústavy. Netreba pritom zabúdat', že spolková vláda stále disponovala právomocou vydávat’ zákony a ústavné zákony na základe čl. III. ods. 2 zákona o mimoriadnych opatreniach týkajúcich sa ústavy, čo iba zvýrazňovalo úplnú degradáciu orgánov zákonodarnej moci.

V protiklade k dôslednej úprave autoritatívneho princípu, stavovský princíp, zakotvený v štvrtej hlave ústavy v čl. 47 a čl. 48, bol upravený iba rámcovo. Malo pritom íst’ o jeden 
zo základných princípov ústavy, ktorý mohol vytvárat' určitú protiváhu autoritatívnemu princípu, a ktorý mal predstavovat' akúsi prirodzenejšiu formu organizácie obyvatel'stva a jeho účasti na moci. Namiesto straníckeho či triedneho frakcionalizmu sa malo obyvatel'stvo politicky organizovat' podl'a jednotlivých stavov, ktoré však mali mat' nielen hospodársku, ale aj kultúrno-spoločenskú povahu. Ústava však vo viacerých prípadoch odkazovala na prijatie obyčajného zákona a vôbec sa nedotkla pálčivej otázky spoločenského významu jednotlivých kultúrno-spoločenských stavov. Vyhla sa tiež otázke hospodárskeho významu jednotlivých povolaní, z ktorých mali hospodárske stavy pozostávat'. Pritom vôbec nie je zrejmé, či by korporatívny princíp vzhl'adom na prirodzenú l’udskú povahu predstavoval skutočne optimálnejší spôsob organizácie spoločnosti a nepriniesol by minimálne také názorové rozpory, aké existovali a existujú medzi jednotlivými politickými zoskupeniami v parlamentnej demokracii. Okrem toho, spolkový ústavný zákon týkajúci sa prechodu $\mathrm{k}$ stavovskej ústave stavy v podstate vylúčil z vplyvu na ich zastupitel’ské orgány, čiže na Spolkovú kultúrnu radu a Spolkovú hospodársku radu, ked’že ich členov menoval spolkový prezident so súhlasom spolkového kancelára.

Hoci, ako sme si uviedli, autori ústavy sa dištancovali od totalitarizmu a v ústave vytvorili určitý priestor pre autonómiu spoločnosti od štátu napríklad inkorporáciou základných práv a slobôd do ústavy alebo zakotvením stavovského či krest’anského princípu, ústava koncentrovala moc do rúk vlády pod vedením spolkového kancelára $\mathrm{v}$ takom rozsahu, že v prípade jej reálnej aplikácie by nepredstavovala nástroj na zabezpečenie stabilného fungovania štátu, ale otvárala by cestu k plíživému nástupu určitej formy autokracie, Koniec-koncov, uvedené naznačoval už politický a spoločenský vývoj, ktorý sa v Rakúsku udial ešte pred prijatím samotného ústavného textu. 